\title{
ARTIKELEN
}

\section{Slachtoffers van bedrijfsgeweld}

\section{Empirische verkenning van een vergeten groep - ook in het herstelrecht}

Katrien Lauwaert

\section{Inleiding}

Onderzoekers schatten dat bedrijfsgeweld een veel groter aantal doden, gewonden en ziektes veroorzaakt dan conventionele criminaliteit (Walklate, 1989; Tombs, 2007). De schadelijke effecten van bedrijfsgeweld zijn voornamelijk gelinkt aan drie domeinen van bedrijfsactiviteit: onveilige milieupraktijken, het op de markt brengen van onveilige producten en gebrekkige veiligheidsmaatregelen in de werkomgeving (Visconti, 2018).

Toch hebben slachtoffers van bedrijfsgeweld tot op heden in de criminologische literatuur betrekkelijk weinig aandacht genoten. Met name in het empirische onderzoek zijn ze in grote mate onder de radar gebleven. Een groot dark number, evenals de courante moeilijkheid om het causale verband tussen specifieke activiteiten van bedrijven en daaraan verbonden specifieke schade te reconstrueren, maken het lastig om de omvang en de fysieke schade van bedrijfsgeweld precies in kaart te brengen. Bovendien stelt zich een perceptieprobleem. Omwille van zijn typische kenmerken (zie verderop) definiëren zowel slachtoffers zelf als de samenleving deze situaties niet snel als een vorm van criminaliteit, laat staan als geweld (Visconti, 2018).

Het Europese project 'Victims and Corporations' koos ervoor om deze vergeten slachtoffergroep zichtbaar te maken. Het verkennende empirische onderzoek naar hun concrete situatie, de kenmerken van hun slachtofferschap en van de opgelopen schade is het onderdeel van het project waarvan in deze bijdrage verslag wordt gedaan. ${ }^{1}$ Ook zoomen we in op de strafrechtelijke afhandeling van dergelijke situaties en op de inschatting die tijdens het project bevraagde bemiddelaars maakten van het potentieel van herstelrecht op dit terrein. Het project 'Victims and Corporations' schonk daarnaast ook aandacht aan de manier waarop de samenleving omgaat met bedrijfsgeweld. Met name werd gekeken naar de publieke aandacht voor deze problematiek, problemen met toegang tot schadefondsen en rechtsbijstand, de houding van overheidsinstanties, de toegankelijk-

1 In een andere bijdrage aan deze aflevering van het Tijdschrift voor Herstelrecht maakt Ivo Aertsen een conceptuele verkenning van de mogelijkheden van herstelrecht bij bedrijfsgeweld op basis van een literatuurstudie. 
heid van diensten voor slachtofferzorg voor deze groep en de reacties van de media. Die thema's blijven echter buiten het bestek van het onderhavige artikel. ${ }^{2}$

\section{Methode}

Voorafgaand aan het empirische onderzoek waar we hier verslag van doen, werd een uitgebreid literatuuronderzoek ${ }^{3}$ uitgevoerd, scanden de onderzoekers nationale en Europese regelgeving ${ }^{4}$ en analyseerden ze een behoorlijk aantal voorbeeldcasussen. ${ }^{5}$ Hierop verder bouwend werd een reeks interviews afgenomen en werden focusgroepen georganiseerd, zowel met slachtoffers van bedrijfsgeweld en hun lotgenotenverenigingen als met professionals die in aanraking komen met deze misdrijven en hun slachtoffers. Onder de deelnemende professionals waren er procureurs des Konings, rechters, advocaten, medewerkers van slachtofferhulp en slachtofferonthaal, een medewerker van een nationale Commissie voor Hulp aan Slachtoffers van Opzettelijke Gewelddaden, bemiddelaars, artsen, een vertegenwoordiger van een niet-gouvernementele organisatie voor mensenrechten en een ombudsman. In totaal ging het om 26 individuele interviews en 8 focusgroepen, uitgevoerd in Italië, Duitsland en België. ${ }^{6}$

\section{Slachtoffers van bedrijfsgeweld}

\section{Omschrijving}

Binnen het brede domein van criminaliteit gepleegd door bedrijven spitste het onderzoek zich toe op gevallen van 'bedrijfsgeweld'. Deze term verwijst naar situaties waarin bedrijven in de loop van hun legale activiteiten misdrijven plegen die schade teweegbrengen aan de gezondheid, integriteit of het leven van natuurlijke personen. Voorbeelden van bedrijfsgeweld kunnen teruggevonden worden op het gebied van milieumisdrijven, productveiligheid, arbeidsomstandigheden en misdrijven in de farmaceutische industrie.

2 Meer informatie over het project, alsook de uitkomsten, waaronder publicaties, videogetuigenissen en trainingspakketten, zijn te vinden op de website van het project: www. victimsandcorporations.eu.

3 Rights of victims, challenges for corporations. Project's first findings, www. victimsandcorporations.eu/wp-content/uploads/2018/04/MidTermReport_First-Findings_rev_ Ott17.pdf.

4 European and international selected legal resources and case law, www.victimsandcorporations. eu/wp-content/uploads/2018/04/VicCorp_Appendix_Selection-of-legal-resources_DEF.pdf.

5 Data collection on leading cases, www.victimsandcorporations.eu/wp-content/uploads/2018/04/ DATA-COLLECTION-ON-LEADING-CASES_DEF.pdf.

6 Per land werden de uitkomsten van de interviews en focusgroepen neergeschreven in een nationaal rapport. Voor België zie Lauwaert, 2017d. De teksten van de drie nationale rapporten zijn gebundeld en samengevat in Needs of victims of corporate violence: empirical findings, Milan: Università Cattolica del Sacro Cuore,www.victimsandcorporations.eu/wp-content/uploads/2018/05/ VictCorp_Empiric.Findings_COMPREHENS.REPORT.pdf. Op basis van de nationale rapporten werden vervolgens een Engelstalige (Lauwaert, 2017a) en een Nederlandstalige (Lauwaert, 2017b) praktijkgids gemaakt en Richtlijnen voor slachtofferzorg en diensten herstelrecht en bemiddeling (Lauwaert, 2017c). 


\section{Voorbeelden}

Enkele voorbeelden van soorten casussen die in het onderzoek aan bod kwamen, geven wellicht een concreter beeld van waar het om gaat.

- Asbest: Duizenden mensen liepen asbestgerelateerde ziektes op door Eternit, een asbestcement, omdat ze als professional met asbest werkten, in de omgeving van asbestfabrieken leefden of samen leefden met asbestarbeiders.

- Rampen veroorzaakt door falen van technische onderdelen: Meer dan honderd personen overleden of geraakten verwond door een treinongeval dat te wijten was aan het technisch falen van een treinwiel.

- Sluikstorten: Een bedrijf dumpte schadelijk afval illegaal op een bestaande stortplaats; water- en grondvervuiling op grote schaal waren het gevolg. Medische tests van de lokale populatie wezen op zorgwekkende resultaten.

- Thalidomide: Een geneesmiddel dat aan zwangere vrouwen toegediend werd, veroorzaakte een aanzienlijke hoeveelheid misvormde pasgeborenen.

- Bloedderivaten: De besmetting van bloedproducten voor hemofiliepatiënten leidde tot de besmetting van een groot aantal mensen met hiv en hepatitis $C$ en B.

- Borstimplantaten: Een bedrijf produceerde defecte borstimplantaten en verkocht deze aan duizenden vrouwen; hun gezondheid werd als gevolg geschaad.

- Luchtvervuiling: Een bedrijf dat milieureglementen schond, veroorzaakte aanzienlijke en langdurige geuroverlast voor de lokale bevolking.

- Petrochemische besmetting: De activiteiten van een petrochemische fabriek werden onderzocht wegens een mogelijk verband met kankergerelateerde ziektes in de regio en met betrekking tot milieuschade.

- Fabrieksbrand: Een textielfabriek in Azië dat voornamelijk textiel produceerde voor een Europese discountzaak, brandde af; veel mensen overleden; de verantwoordelijkheid van het Europese bedrijf werd onderzocht.

Enkele Belgische casussen beschrijven we wat meer in detail, omdat ze de typische kenmerken van situaties en slachtofferschap van bedrijfsgeweld, die we verderop uiteenzetten, goed illustreren.

\section{Eternit - besmetting met asbest}

Het bedrijf Eternit, eigendom van een van de rijkste families van België, heeft gedurende tientallen jaren materialen geproduceerd op basis van asbest in Kapelle-op-den-Bos, een gemeente in Vlaanderen. Veel families in die regio waren, en zijn nog steeds, economisch afhankelijk van de fabriek, die nog altijd actief is, maar de productie van asbest heeft stilgelegd in 1998, slechts één jaar voordat het gebruik ervan illegaal werd. Eternit, een internationaal vertakt bedrijf, ontwikkelde al vroeg een uitgebreide lobby voor het gebruik van asbest. De productie en het lobbyen voor asbest bleven gedurende lange tijd verdergaan ondanks het bestaan van studies die aantoonden dat asbest schadelijke gevolgen heeft voor de fabrieksarbeiders en hun gezinnen die in de buurt woonden. Het bedrijf richtte een privaat fonds op om werknemers en hun families die mesothelioom opgelopen hadden, een asbestgerelateerde en dodelijke kanker, te compen- 
seren. De werknemers moesten in ruil voor de financiële compensatie een vertrouwelijkheidsclausule tekenen en het was hun niet toegelaten juridische stappen tegen het bedrijf te ondernemen. De schadelijke effecten van asbest hebben een zeer lange latentieperiode, die kan oplopen tot veertig jaar. In 2007 werd een nationaal asbestfonds opgericht om slachtoffers van mesothelioom en asbest compensatie te bieden. Ook hier geldt dat wie een beroep doet op het asbestfonds, zijn recht om tegen het betrokken bedrijf te procederen verliest. Er zijn zeer weinig rechtszaken, strafrechtelijke en burgerrechtelijke, aangespannen tegen het bedrijf, ondanks het groeiende aantal sterfgevallen gerelateerd aan asbestblootstelling. In tegenstelling tot andere landen kwam er in België nooit een strafrechtelijke uitspraak. In de tot nog toe enige (burgerrechtelijke) rechtszaak waarin er een uitspraak van de rechter kwam, werd het bedrijf veroordeeld tot het betalen van een schadevergoeding van $€ 250.000$ aan het slachtoffer. In hoger beroep werd de veroordeling bevestigd, maar de te betalen schadevergoeding verlaagd tot $€ 25.000$. De procesgang duurde achttien jaar.

\section{Brand in sociale huisvesting in Bergen}

Een sociaal woningblok vatte vuur op 20 februari 2003 in de stad Bergen. De brand verspreidde zich zeer snel, er waren 26 gewonden en 7 personen kwamen om het leven. Een strafonderzoek werd gestart en het strafproces vond plaats in 2013. De sociale huisvestingsmaatschappij werd veroordeeld voor onopzettelijke doodslag als gevolg van een tekort aan voorzorgsmaatregelen. De sociale huisvestingsmaatschappij werkte in een milieu dat gekarakteriseerd was door een tekort aan organisatie en nam veiligheidskwesties niet serieus. De CEO en de voorzitter van het bestuur werden niet veroordeeld. De slachtoffers kregen een financiële schadevergoeding meer dan tien jaar nadat het drama plaatsvond.

\section{Gasexplosie in Ghislenghien}

Op 30 juli 2004 veroorzaakte een onopzettelijk gaslek in een hogedrukgasleiding op een bouwplaats een enorme explosie in Ghislenghien. 24 personen kwamen onmiddellijk om het leven en 132 anderen raakten gewond. Het was de grootste technologische ramp ooit in België. Een strafproces vond plaats, waarin 600 burgerlijke partijen betrokken waren. In eerste aanleg werden slechts drie van de veertien verdachten schuldig bevonden. Ze werden alle drie veroordeeld voor onopzettelijke doodslag. In beroep werden acht van de veertien verdachte personen schuldig bevonden. Ze werden veroordeeld voor gebrek aan zorgvuldigheid. Naast de strafrechtelijke procedures spanden slachtoffers ook burgerrechtelijke rechtszaken aan. De kwestie omtrent de financiële compensatie van de burgerlijke partijen was zeer complex. Tien jaar na de ramp waren er nog steeds schadevergoedingszaken waarin geen beslissend oordeel was geveld. De gasexplosie van Ghislenghien kwam uitvoerig in de media aan bod en genoot sterke politieke aandacht. Een slachtoffervereniging werd opgericht en er werd een jaarlijkse herdenking georganiseerd op de plaats van het ongeval. Als gevolg van de ramp van Ghislenghien werd een wet aangenomen op grond waarvan slachtoffers van technologische rampen gecompenseerd worden voor geleden fysieke schade zonder dat ze moeten wachten totdat de verantwoordelijkheden bepaald worden in 
gerechtelijke procedures. Het vormde een antwoord op de klachten van vele slachtoffers die jaren hadden moeten wachten voordat ze een schadevergoeding ontvangen hadden. Een fonds werd opgericht om deze schadevergoeding mogelijk te maken. Verzekeringsbedrijven dragen bij aan het fonds en na de gerechtelijke procedures regelen ze onderling de verdeling van de schadevergoeding, zoals door de rechtbank bepaald.

\section{Treinongeval in Wetteren}

Een goederentrein ontspoorde in de nacht van 4 mei 2013 nabij Wetteren. Verschillende wagons die acrylonitril bevatten, vatten vuur. Eén slachtoffer stierf, ongeveer honderd personen werden opgenomen in het ziekenhuis met symptomen van vergiftiging en ongeveer tweeduizend personen moesten uit hun huizen geëvacueerd worden. De giftige inhoud van de treinwagons, gemengd met het gecontamineerde water dat gebruikt werd om het vuur te blussen, belandde in de riolering, waardoor de omgeving rond de plaats van het treinongeval vervuild raakte. De verdampte acrylonitril drong door tot in de omstaande huizen. Een strafrechtelijk onderzoek werd opgestart.

\section{Specifieke kenmerken van slachtofferschap van bedrijfsgeweld}

Bepaalde kenmerken zijn typisch voor bedrijfsgeweld. Hieronder lijsten we er een aantal op. Niet alle kenmerken zijn van toepassing op elk geval van bedrijfsgeweld. Deze kenmerken beïnvloeden de slachtofferschapservaring van personen, hun noden en wat er verwacht wordt van professionals die met hen werken. In die zin zijn ze ook van belang om in te schatten of en op welke manier herstelrechtelijke processen nuttig ingezet kunnen worden in geval van bedrijfsgeweld.

\section{Het bedrijf als dader}

Hoewel ze zelden vermeld worden als specifieke groep van kwetsbare slachtoffers, is het duidelijk dat slachtoffers van bedrijfsgeweld bijzonder kwetsbaar zijn doordat de dader een bedrijf is. Dit wordt duidelijk op verschillende manieren. In het algemeen is de relatie tussen het bedrijf en het individu dat schade lijdt gekenmerkt door een ongelijke machtsverhouding. Dit is een facet dat niet mag onderschat worden. Er is meestal ongelijkheid op het vlak van correcte informatie wat betreft de feiten (wat heeft het bedrijf precies gedaan), de veroorzaakte schade en de risico's voor de toekomst. Vaak is er specifieke technische expertise nodig om de oorzaak-gevolgketen bloot te leggen en te begrijpen; het betreft expertise waarover de bedrijven wel, maar de slachtoffers niet beschikken. De nodige expertises laten uitvoeren is vaak een kostbare zaak, zodat slachtoffers de facto afhankelijk zijn van het initiatief van publieke instanties om een en ander te bewijzen. Ook de mogelijkheid om juridische stappen te ondernemen ligt grotendeels in het voordeel van het bedrijf, dat veel meer middelen tot zijn beschikking heeft.

Het is voorts lastig voor slachtoffers om in verzet te gaan tegen praktijken van een bedrijf waarvan ze economisch of op andere wijze afhankelijk zijn. De Eternitcasus illustreert dit overvloedig. Nog steeds zijn er buurtbewoners die het onge- 
hoord vinden om zich te keren tegen het bedrijf dat hun familie verscheidene generaties lang werk heeft verschaft. In de zaak omtrent de bloedderivaten waren de hemofiliepatiënten letterlijk afhankelijk van de producten van het farmaceutische bedrijf om te kunnen overleven.

Het bedrijf wordt voorts vaak beleefd als een soort Goliath waar slachtoffers als de kleine David moeten tegen opboksen. Vaak blijft de reus een ondoorzichtige, onpersoonlijke en complexe entiteit waarvan men niet weet hoe die aan te spreken. Een identificeerbare individuele schuldige is immers meestal niet aan te wijzen. Dit gevoel wordt nog versterkt wanneer het bedrijf een multinational is en het slachtofferschap zelfs over de landsgrenzen heen reikt. Dit laatste werd heel duidelijk in de casus van de Aziatische textielfabriek, waar de aansturing van de werkzaamheden vanuit Duitsland gebeurde.

Vaak is er ten slotte een verstrengeling van de belangen van het bedrijf en de (lokale of nationale) overheden en politiek. Bij de brand in de sociale huisvesting in Bergen werden de bewoners tijdens een persconferentie onmiddellijk na de feiten met de vinger gewezen. De lokale procureur/officier van justitie startte enkel een onderzoek naar brandstichting. Een geëngageerde groep advocaten legde in samenwerking met de bewoners echter een hele reeks veiligheidsproblemen bloot en diende tegen de beheerders van het gebouw een strafklacht in wegens onvrijwillige doodslag. Er waren allerlei aanwijzingen dat de politie het onderzoek vertraagde. De burgemeester, ook hoofd van de lokale politie, was lid van de raad van bestuur van de sociale huisvestingsmaatschappij die het gebouw beheerde. De officier van justitie wilde de zaak aanvankelijk niet voor de rechter brengen; pas na uitgebreide media-aandacht die werd gegenereerd door een persconferentie van de groep slachtoffers en hun advocaten, kwam de zaak toch op zitting.

Ook het economische belang van een bedrijf kan een machtsfactor van formaat zijn met invloed op de aanpak van de overheid. België, dé thuisbasis van bedrijf Eternit en land met lange tijd de belangrijkste productie van asbestcement, was één van de laatste landen waar asbestproductie verboden werd. Het asbestfonds, een initiatief van de overheid, wordt gespijsd door bijdragen van alle Belgische bedrijven, en niet - zoals de slachtoffers het graag zagen - in de eerste plaats door het verantwoordelijke bedrijf. Slachtoffers die op het fonds een beroep doen, doen daarmee automatisch afstand van hun recht om tegen het bedrijf te procederen. In tegenstelling tot in vele andere landen zijn er nagenoeg geen strafrechtelijke onderzoeken opgestart tegen Eternit en kwam er tot nog toe geen enkele strafrechtelijke veroordeling.

\section{Gebrek aan erkenning}

Personen die lijden als gevolg van bedrijfsgeweld worden vaak niet onderkend als slachtoffers van criminaliteit door zichzelf, door professionals en door het brede publiek. De intrinsieke eigenschappen van bedrijfsgeweld verhinderen dat men het als criminaliteit bestempelt. Dit vraagt enige toelichting.

Vooreerst is er onwetendheid. De personen zelf zijn zich er soms niet van bewust dat ze slachtoffer geworden zijn. Schaarse of nauwelijks bekende wetenschappelijke informatie over het schadeveroorzakende feit draagt bij tot een onduidelijk oorzakelijk verband. Ouders van een misvormde pasgeborene realiseren zich bij- 
voorbeeld niet dat die situatie verband houdt met de inname van bepaalde medicatie door de moeder. Vaak is er een lange incubatietijd en is het oorzakelijke verband onduidelijk omdat het slachtofferschap verschijnt lange tijd na de feiten of daden die het veroorzaakten. Bewoners met gezondheidsklachten maken bijvoorbeeld niet de link met een stortplaats in de buurt die er al jaren is. De dodelijke ziekte mesothelioom manifesteert zich tot veertig jaar na contact met asbestvezels.

Daarenboven worden bedrijven vandaag door de brede samenleving nog steeds niet gemakkelijk gezien als daders, zodat, zelfs als er schadeveroorzakend gedrag is, de feiten vaak niet beschouwd worden als een 'echt' misdrijf of als echt geweld. Dit wordt versterkt door de opvatting dat echt geweld gaat over een opzettelijke, directe fysieke actie van één (natuurlijke) persoon ten aanzien van een andere (natuurlijke) persoon. Bij bedrijfsgeweld is de veroorzaakte schade echter niet interpersoonlijk of direct, maar eerder indirect en het gevolg van beslissingen - acties of vormen van verzuim - die genomen werden door complexe organisaties. Bij bedrijfsgeweld is de schade bovendien meestal onvrijwillig. $\mathrm{Ze}$ is het gevolg van beslissingen die genomen werden om winst te maken, niet om opzettelijk schade te berokkenen.

Ten slotte, wanneer de blootstelling aan de schade vrijwillig was, bijvoorbeeld door een bepaalde levensstijl of bezigheid, of door de keuze om gebruik te maken van een bepaald product, definiëren mensen zich niet snel zelf als slachtoffers van criminaliteit.

\section{Collectief slachtofferschap}

Bedrijfsactiviteiten veroorzaken vaak schade aan vele mensen. Het slachtofferschap kan betrekking hebben op een lokale gemeenschap. De brand in de sociale huisvesting is daar een goed voorbeeld van of de gezondheidsproblemen door een naburig sluikstort. Maar het kan ook verspreid zijn over vele landen, zoals bijvoorbeeld blijkt uit de casus van de defecte borstimplantaten, die slachtoffers maakten in diverse Europese landen, wat leidde tot het zogenoemde PIPschandaal. Het slachtofferschap kan ten slotte plaatsvinden op een bepaalde plaats waar slachtoffers van zeer verschillende regio's samenkomen op een bepaald moment, zoals het geval was bij de gasexplosie op het industrieel terrein van Ghislenghien. Slachtoffers kunnen schade oplopen door een plotse gebeurtenis (brand, gasexplosie, treinramp...) of het slachtofferschap kan over de tijd heen uitgespreid zijn (inademing van asbestvezels of vervuilde lucht, inname defecte medicatie, gebruik van gecontamineerd water...). Het collectieve karakter kan met andere woorden heel zichtbaar en onmiddellijk duidelijk zijn of pas na een hele tijd tot uiting komen.

\section{Geaccumuleerde kwetsbaarheid}

Slachtoffers van bedrijfsgeweld stapelen nogal eens kwetsbaarheidsfactoren op. Hiervoor beschreven we reeds de kwetsbaarheid die gelieerd is aan het feit dat de dader een bedrijf is en te maken heeft met de ongelijke machtsverhouding en de complexere situatie in vergelijking met conventionele misdrijven. Daar bovenop komt vaak de omvang van de schade, die zeer indringend kan zijn (zie verderop). 
Vele slachtoffers uit de onderzochte casussen bevonden zich reeds vóór het slachtofferschap in een kwetsbare positie, omdat ze al ernstig ziek waren (bijv. hemofiliepatiënten), kansarm waren (bijv. huurders van sociale woningen), afhankelijk van het bedrijf voor hun werk (bijv. asbestarbeiders) of in een situatie van uitbuiting zaten (bijv. arbeiders in een textielfabriek). Wanneer het slachtoffer in dienst is bij het bedrijf, voelt het slachtofferschap vaak aan als een schending van vertrouwen. Daarenboven worstelt men vaak met schuldgevoelens wanneer men zelf actief deelnam aan de activiteiten die de schade veroorzaakten, bijvoorbeeld door het aankopen van schadeverwekkende producten of wanneer men gewerkt heeft in de fabriek die de schade veroorzaakt.

\section{Verhoogd risico op herhaald slachtofferschap en secundaire victimisatie}

Slachtoffers van bedrijfsgeweld zijn vaak blootgesteld aan voortdurend slachtofferschap: grond- en watervervuiling worden niet ineens gezuiverd, defecte implantaten worden niet gemakkelijk verwijderd, mensen nemen schadelijke medicatie gedurende een bepaalde tijd voordat ze de schadelijkheid ervan ontdekken. Deze voorbeelden tonen aan dat slachtofferschap een lange tijd kan duren vooraleer het ontdekt wordt; maar ook nadat het zichtbaar geworden is, kan het verder duren door de onmogelijkheid om de oorzaak van de schade op korte termijn weg te nemen. Het kan dan ook erg moeilijk worden om het slachtofferschap 'af te sluiten'. De slachtoffers kunnen nog steeds in niet-gezuiverde gebieden leven, of met hiv of asbest besmet zijn zonder dat de gerelateerde ziekte zich reeds ontwikkelde. Anders gezegd, voor bepaalde groepen van slachtoffers impliceert het slachtofferschap een permanent gevaar.

Secundaire victimisatie door uiteenlopende instanties is typisch wanneer de causale link tussen de bedrijfsactiviteit en de schade onduidelijk is (waardoor men niet geloofd wordt) of wanneer de autoriteiten de situatie niet willen of kunnen aanpakken.

\section{Schade veroorzaakt door bedrijfsgeweld}

Net zoals voor andere ernstige misdrijven is de schade praktisch, fysiek, mentaal en emotioneel, economisch en sociaal. Deze soorten schade worden niet afzonderlijk ervaren, maar gecombineerd of op elkaar volgend beleefd.

\section{Fysieke gevolgen}

De fysieke schade is meestal het eerste effect van het bedrijfsgeweld, hoewel de incubatietijd lang kan zijn en de causale link moeilijk te maken. Zichtbare fysieke schade kan variëren van de dood en permanente onbekwaamheden tot verwondingen en serieuze (zowel op korte als op lange termijn) gezondheidsschade. Het kan zelfs schade aan de foetus of de pasgeborene omvatten, zoals het geval was in de thalidomide-casus. In sommige gevallen zijn de symptomen aspecifiek en moeilijk te diagnosticeren. In die gevallen is het gebruikelijk voor artsen, werkgevers of het informele sociale netwerk om ervan uit te gaan dat het voornamelijk een psychologische of psychosomatische toestand betreft (bijv. fysieke gevolgen 
van het gebruik van een houtbeschermingsmiddel; fysieke gevolgen van fracking; fysieke gevolgen van explosiefdetectoren die door luchthavenpersoneel gebruikt werden).

Economisch verlies en de emotionele en/of mentale problemen zijn eerder een neveneffect, maar daarom zijn ze niet minder ernstig.

\section{Financiële en psychologische gevolgen}

Vaak is het zo dat slachtoffers tijdelijk of permanent werkonbekwaam worden, waardoor ze financiële problemen ervaren. Professionals benadrukken evenzeer de grote uitdaging voor slachtoffers die een familielid zijn kwijtgeraakt, zeker als de overledene de kostwinner van de familie was. In het geval van de Aziatische textielfabriek die afbrandde, ervaarden ouders die afhankelijk waren van het inkomen van hun overleden zonen totale financiële en economische onzekerheid; de vrouwen van de overledene moesten terugkeren naar hun eigen families, wat betekende dat ze werden blootgesteld aan de oude, patriarchale cultuur.

Veel slachtoffers ervaren abrupt veranderde levensomstandigheden en hebben het lastig zich daaraan aan te passen. De fysieke schade, de ervaring niet gehoord te worden in combinatie met uitgesloten te worden door het sociale informele netwerk en van andere belangrijke ruimtes zoals de werkplaats, veroorzaken enorme mentale en emotionele moeilijkheden. Een toenemend scepticisme, angst en zelftwijfel zijn vaak voorkomende effecten waarmee slachtoffers te maken krijgen. Wanneer slachtoffers zelf hebben bijgedragen tot het schadeberokkenende gedrag zorgt dat voor extra stress. Zo droeg een door hemofiliemedicatie met hiv besmet slachtoffer de ziekte onbewust over aan zijn partner, die uiteindelijk overleed.

\section{Sociale gevolgen}

Ook sociale gevolgen kunnen indringend zijn. Slachtofferschap zorgt voor spanningen binnen de relaties van de getroffen personen en kan leiden tot de ontbinding van families en andere informele netwerken. Zo konden verscheidene koppels niet omgaan met de geboorte van een gehandicapt kind dat te wijten was aan een medicijn dat de moeder had ingenomen. In sommige gevallen verliezen mensen sociale status. Slachtoffers van een defectief medicijn gaven aan dat ze sociaal gestigmatiseerd werden omwille van de lichamelijke misvormingen waarmee ze geboren werden. Het sociale leven van zwaar verbrande slachtoffers was aanzienlijk gereduceerd door hun lichamelijke verminkingen. In het geval van vervuiling worden ganse gemeenschappen soms getroffen, zowel fysiek als emotioneel. In sommige gevallen werd het moeilijk of onmogelijk om het ouderschap aan te gaan, door de fysieke gevolgen van de schade en omdat de gezondheidstoestand van het slachtoffer als te precair beoordeeld werd om adoptie toe te staan.

\section{Ervaringen met het (straf)rechtssysteem}

Uit de meningen van slachtoffers die we tijdens het project opvingen, leerden we dat ze het belangrijk vinden dat hun zaak voor de strafrechter wordt gebracht. De 
strafprocedure is een gelegenheid om de belangstelling en aandacht voor een probleem te verhogen. Het is ook een manier om bewijs te kunnen laten verzamelen wanneer de slachtoffers over onvoldoende middelen beschikken om dat zelf te (laten) doen. Het is vaak de enige mogelijkheid om een vergoeding te vragen wanneer alle andere compensatiesystemen mislukken en het enige kanaal dat leidt tot een publieke erkenning van de slachtoffers. Meer dan op het verkrijgen van schadevergoeding zijn slachtoffers immers uit op publieke vaststelling van de waarheid met aanduiding van verantwoordelijkheden.

Tegelijkertijd stelden we doorheen de casussen vast dat bij lange niet alle gevallen van bedrijfsgeweld kunnen rekenen op dezelfde belangstelling. Zowel de overheid, de gerechtelijke instanties als de samenleving in haar geheel besteden veel meer aandacht aan voorvallen van plots, collectief en zichtbaar slachtofferschap; dit zijn vaak de zogenoemde rampen. Deze situaties trekken veel media-aandacht en politieke welwillendheid aan. De hele maatschappij voelt zich betrokken. Slachtoffers worden onmiddellijk erkend in hun slachtofferstatus en de situatie wordt aangepakt vanuit een brede lens. Daar hoort vaak ook actie vanuit justitie bij.

Gevallen van bedrijfsgeweld creëren enorme uitdagingen, niet alleen voor slachtoffers, maar ook voor het strafrechtsysteem zelf.

Bij collectief slachtofferschap dient men aangepaste methoden te hanteren om grote groepen slachtoffers te informeren en hun deelname aan het proces te organiseren. Snelle berichtgeving zonder de privacy van slachtoffers te schenden, het organiseren van collectieve registratie als burgerlijke partij of benadeelde persoon en de aanwezigheid van grote groepen bij hoorzittingen zijn uitdagingen van formaat. De accommodatie in de rechtbanken is doorgaans totaal onaangepast. Hoewel er in het verleden soms ad hoc oplossingen zijn gezocht (bij terechtzittingen omtrent gemediatiseerde rampen), zijn er andere gevallen waarbij de aanwezigheid van groepen slachtoffers bij de terechtzitting niet mogelijk gemaakt werd. Dit wordt door slachtoffers aangevoeld als een pijnlijk gebrek aan erkenning door het strafrechtsysteem.

Door lange incubatieperiodes vinden onderzoeken en strafprocedures lang na de schadelijke activiteiten plaats. In de tussentijd zijn herinneringen vervaagd, willen mensen het verleden niet meer oprakelen of is het bewijs verdwenen. Als er te veel tijd tussen de feiten en de strafrechtelijke procedure zit, kan dit leiden tot vrijspraak of niet-vervolging wegens verjaring van de feiten. Dit is voor slachtoffers moeilijk te begrijpen en te verteren. De verjaring bij lange latentieperiodes is een structureel probleem. Zoals hiervoor reeds vermeld, is ook vaak zeer gespecialiseerde wetenschappelijke expertise nodig om een oorzakelijk verband tussen feiten en schade te kunnen aantonen. De bekendmaking van de persoonsgegevens en de onthulling van de persoonlijke geschiedenis van slachtoffers is vaak een negatief gevolg van de openbaarheid van het strafproces.

Over het algemeen willen vele slachtoffers bijdragen aan het onderzoek en hun zeg doen tijdens de strafprocedure, zij het als getuige of als deelnemende partij. Een belangrijke reden hiervoor is de wens om te voorkomen dat de feiten zich zouden herhalen en om het schadelijke gedrag te stoppen. Op deze manier kunnen ze tenminste vermijden dat andere mensen gelijkaardige situaties moeten 
meemaken. Wat bij bedrijfsgeweld vereist is om herhaling van de feiten te voorkomen, overstijgt echter vaak de situatie van een individuele overtreder; eerder gaat het om structurele of systemische veranderingen. Het strafrechtsysteem is slecht uitgerust om dat soort veranderingen te bewerkstelligen.

Voor slachtoffers gaapt er dan ook vaak een kloof tussen de verwachtingen ten aanzien van het strafproces en de uitkomsten ervan. Vanwege de vele, bovengenoemde obstakels leveren strafrechtelijke procedures bijvoorbeeld vaak geen vergoeding op voor de slachtoffers, ondanks het geleverde bewijs van schade door het gepleegde misdrijf. Slachtoffers reageren met grote teleurstelling, onbegrip, wanhoop of blijven achter met een gevoel van secundaire victimisering. Het vertrouwen van de slachtoffers in het hele strafrechtsysteem kan op die manier een flinke deuk krijgen.

Als we dit alles bij elkaar leggen, dringt zich bijna als vanzelfsprekend de vraag op of er via herstelrechtelijke processen beter tegemoet zou kunnen worden gekomen aan de noden en behoeften van slachtoffers van bedrijfsgeweld. Een meer flexibele, holistische aanpak lijkt in elk geval aangewezen, waarbij groepen slachtoffers direct betrokken kunnen worden, mensen hun zeg kunnen doen, de uitkomsten beter afgestemd worden op de noden in de betrokken casus en de strikte eisen inzake bewijs en verstreken tijd overstegen kunnen worden. Dat vereist wel vrijwillige deelname, ook aan de daderkant. De vraag is of het realistisch is dit bij bedrijfsgeweld te verwachten.

\section{Een blik vanuit de bemiddelingspraktijk in België}

\section{Stand van zaken in België}

In het Europese project 'Victims and Corporations' werd nagegaan hoe het in de Belgische context staat met bedrijfsgeweld in herstelrechtelijke praktijken. Dit gebeurde via interviews en een focusgroep. ${ }^{7}$ Daaruit blijkt dat in de praktijken van bemiddeling tussen slachtoffers en daders gevallen van bedrijfsgeweld echt zeldzaam zijn. Dit is zowel het geval voor slachtoffer-daderbemiddeling als voor bemiddeling in strafzaken. Slachtoffer-daderbemiddeling is georganiseerd parallel aan de strafprocedure (art. 553-554 Wetboek van Strafvordering (Sv)). Een standaardbemiddeling in deze context betreft een conflict tussen twee natuurlijke personen. Een bemiddeling met een rechtspersoon als dader is uiterst zeldzaam. Af en toe komen wel conflicten met rechtspersonen als slachtoffer in bemiddeling terecht. Dat is bijvoorbeeld het geval bij diefstal of overvallen met geweld. Bij bemiddeling in strafzaken wordt de bemiddeling georganiseerd als diversiemechanisme binnen de strafrechtelijke procedure (art. 216ter Sv). Wanneer het gaat over diversiemechanismen, worden bedrijven echter eerder benaderd met een voorstel tot transactie. In dat geval betaalt het bedrijf een som geld aan de staat

7 In concreto werden twee beleidsverantwoordelijken voor bemiddeling in strafzaken geïnterviewd. De focusgroep bestond uit vier bemiddelaars met tien tot zestien jaar ervaring, een bemiddelaar in opleiding en een staflid van de centrale coördinatie van Moderator. Forum voor herstelrecht en bemiddeling vzw, de organisatie die slachtoffer-daderbemiddeling in Vlaanderen organiseert. 
en in ruil zal de zaak niet voor de rechtbank verschijnen. Formeel zijn er nochtans geen criteria die bedrijfsgeweld uitsluiten van beide genoemde vormen van bemiddeling.

\section{Potentieel, maar wel specifieke aandachtspunten}

De bevraagde bemiddelingsprofessionals zagen situaties van bedrijfsgeweld nochtans als potentiële gevallen voor bemiddeling. Het is een onontgonnen terrein waarin bemiddeling zinvol is, zo stelden ze, en zelfs heel interessant kan zijn, omdat deze zaken gepaard gaan met boosheid, veel vragen, sterke emoties en behoefte aan communicatie, erkenning en herstel. Bemiddelaars zien geen grote obstakels. De belangrijkste principes van bemiddeling zouden kunnen worden gehandhaafd.

Bepaalde kenmerken van situaties van bedrijfsgeweld, die belemmeringen zijn gebleken voor het opstarten of welslagen van een strafrechtelijke procedure, zien de bevraagde bemiddelaars niet als een obstakel voor de opstart van of het goede verloop van een bemiddeling. De loyaliteit van het slachtoffer ten aanzien van de dader, gevoelens van medeverantwoordelijkheid en schuld bij het slachtoffer zijn vaak ook sterk aanwezig in situaties van intrafamiliale seksuele misdrijven, waar bemiddelaars goed mee kunnen werken. Ook een gedeeltelijk onduidelijk of moeilijk te bewijzen causaal verband tussen de activiteiten van de dader en de schade die de slachtoffers hebben geleden hoeft geen zwaar obstakel te zijn. Dat slachtoffers ernstige schade ervaren, daarmee aan de slag willen, maar deze niet per se definiëren in termen van strafbaar gedrag is ook herkenbaar, bijvoorbeeld vanuit bemiddeling bij ernstige verkeersmisdrijven.

Bepaalde andere kenmerken van bedrijfsgeweld vereisen volgens de bemiddelaars wél specifieke aandacht of maken dat men best minder gekende/gebruikte herstelrechtelijke methodieken inschakelt. We bespreken de belangrijkste.

\section{De houding van de bedrijven}

Erkenning van een minimum aan betrokkenheid en verantwoordelijkheid is nodig om de communicatie tussen de partijen op gang te kunnen trekken. Dat kan problematisch zijn als het bedrijf doet alsof het niets te maken heeft met de schade of als het de verantwoordelijkheid naar andere actoren probeert af te schuiven.

Uit de uitgevoerde casusanalyse en de interviews met slachtoffers en diverse professionals die met slachtoffers van bedrijfsgeweld omgaan, blijkt dat de slachtoffers de sterke wens hebben dat iemand verantwoordelijkheid opneemt voor de schade die zij hebben geleden. Deze verwachting wordt niet vaak ingelost. De houding van de betrokken bedrijven lijkt sterk te worden gedreven door mogelijke juridische (en financiële) gevolgen voor het bedrijf en door reputatiebehartiging om imagoschade te voorkomen. Dit zorgt voor een genuanceerde houding van de bedrijven in geval van duidelijk slachtofferschap en een duidelijke band met het bedrijf (vaak situaties van plotseling, collectief slachtofferschap). We zagen in de geanalyseerde casussen dat bedrijven in dat geval bijvoorbeeld bereid waren om publiekelijk verontschuldigingen aan te bieden, een schenking te doen of een 
noodfonds op te zetten om de slachtoffers financieel te ondersteunen of dat ze toestemming gaven om een herinneringstuin te installeren op het terrein van het bedrijf.

In veel andere gevallen benoemden slachtoffers de houding van het bedrijf als negatief, of zelfs zeer pijnlijk, of angst veroorzakend. Het ging om bedrijven die zich heel onverschillig opstelden ten opzichte van de slachtoffers, waarbij (bijvoorbeeld) geen contactpersoon werd aangeduid binnen het bedrijf; bedrijven die de feiten en de schadelijke effecten strikt bleven ontkennen en in elk geval geen verantwoordelijkheid opnamen voor deze effecten; bedrijven die weigerden om excuses aan te bieden; bedrijven die niet toelieten dat een gedenkteken werd geplaatst op de plaats van de feiten; bedrijven die de slachtoffers de schuld gaven of zelfs slachtoffers probeerden 'om te kopen' door middel van compensatieovereenkomsten. Die overeenkomsten bevatten namelijk soms vertrouwelijkheidsbedingen, zodat de slachtoffers niet konden praten over hun zaak of over de overeenkomst, of bedingen waarbij men het bedrijf vrijstelde van verantwoordelijkheid als voorwaarde voor een financiële regeling. Financiële regelingen en financiële compensatie werden door de slachtoffers in de interviews aangeduid als 'verachtelijke voorstellen' waar ze moeten mee omgaan. De keuze tussen het aanvaarden van een financiële compensatie dan wel vechten voor meer collectieve vormen van herstel en sanering (activering van sociale diensten of medische hulp, opkuis van vervuilde sites, enz.) veroorzaakte bij de slachtoffers ethische dilemma's alsook spanningen tussen slachtoffers en slachtofferverenigingen.

\section{Collectief slachtofferschap}

Als het slachtofferschap (zoals vaak voorkomt) collectief is, moet de praktische organisatie van de bemiddeling aangepast worden en verschilt het proces van de gebruikelijke een-op-eendialoog. Men kan zich volgens de bevraagde bemiddelaars daarbij laten inspireren door methodieken die worden gebruikt bij collectief slachtofferschap op andere gebieden dan bedrijfsgeweld. De bemiddelaars zagen diverse pistes hiervoor.

Men kan onderdelen van het bemiddelingsproces collectief maken en andere onderdelen toch op individueel niveau houden. Zo kan men een collectieve informatiesessie organiseren over de mogelijkheid van bemiddeling, wat het inhoudt en wat de mogelijke uitkomsten en gevolgen zijn. Daarna kunnen geïnteresseerden een meer geïndividualiseerd proces met de bemiddelaar starten. Het luisteren naar en de erkenning van de individuele verhalen blijft immers een essentieel onderdeel van de bemiddeling; verwachtingen worden verduidelijkt en er wordt verkend hoe men tot een voor de partijen bevredigende situatie kan komen.

Bemiddelaars kunnen werken met de methode van peacemaking circles. Dit is een werkvorm waar niet enkel de directe (fysieke) slachtoffers en de directe veroorzakers van de schade samenkomen, maar waarbij ook andere betrokkenen, zoals bezorgde of geïnteresseerde burgers en/of professionals, deel kunnen uitmaken van het groepsgesprek. Een dergelijk gesprek wordt terdege voorbereid en in goede banen geleid door één of twee circle keepers, die ervoor zorgen dat ieder vrijuit kan spreken vanuit zijn/haar individuele perspectief of vanuit de belangen van de (lokale) gemeenschap. Op deze wijze wordt een brug geslagen tussen de ver- 
schillende perspectieven en wordt vaak op creatieve wijze bijgedragen tot een oplossing of tegemoetkoming.

Men kan werken met dialooggroepen, waarbij slachtoffers en daders van nietgerelateerde strafbare feiten samenkomen om uit te wisselen over thema's die verband houden met criminaliteit, zoals het nemen van verantwoordelijkheid, herstel en bestraffing. Deze dialooggroepen zijn voor de deelnemers minder bedreigend dan een rechtstreekse slachtoffer-daderbemiddeling. Zij kunnen fungeren als eyeopener, waarbij men, door de persoonlijke ontmoeting met gelijkaardige 'gevallen', inzicht verwerft in de problematiek aan beide kanten.

In buurtbemiddeling worden methoden gebruikt om om te gaan met conflicten tussen groepen burgers, tussen groepen burgers en de lokale overheden, of tussen een buurman en een groep andere buren. Deze methode kan worden aangepast aan gevallen van slachtofferschap van bedrijfsgeweld. In een eerste fase worden betrokken of bezorgde bewoners van de buurt onderling samengebracht om de noden te verkennen. In een tweede fase gaat men dan vertegenwoordigers van het bedrijf in kwestie uitnodigen om een (goed begeleid) gesprek op gang te brengen en om naar een afdoend antwoord of afdoende oplossing toe te werken. Ook hier zullen de bemiddelaars de partijen trachten te motiveren tot deelname door aan te tonen dat een dergelijk (groeps)gesprek in grote mate tot beider voordeel kan strekken.

\section{Feitelijke plegers en verantwoordelijken niet meer actief in het bedrijf}

Ten gevolgde van de lange tijd die vaak verstreken is sinds het plegen van de feiten, zouden de feitelijke plegers en de verantwoordelijken niet meer aanwezig kunnen zijn. Het betrokken bedrijf kan aangemoedigd worden om een vertegenwoordiger te vinden om verantwoordelijkheid te nemen namens de instelling. Inspiratie kan hiervoor gevonden worden bij de werkmodellen die in België en elders werden ingevoerd met betrekking tot historisch institutioneel misbruik. Ook daar gaat het doorgaans om diverse en complexe vormen van geweld die tot stand gekomen zijn en konden voortbestaan precies omwille van situaties van ongelijkheid en macht binnen een organisatiecontext. Ook daar laat de victimisatie vaak diepe sporen na op diverse levensdomeinen van betrokkenen. Wegens het verstrijken van de verjaringstermijn kan gerechtelijke actie vaak niet meer ondernomen worden. Toch werden, mede op basis van de maatschappelijke druk en de morele verantwoordelijkheid van de betreffende instelling, antwoorden uitgewerkt op basis van bemiddeling, hulpverlening en eventueel ook arbitrage. Het bieden van erkenning, aanreiken van excuses en voorstellen van (financiële) hulp kunnen hiervan het resultaat zijn.

\section{Machtsonevenwicht}

Het machtsevenwicht tussen partijen in de bemiddeling zou bijzondere aandacht vereisen. Aan de ene kant kan er een onevenwicht bestaan tussen de vertegenwoordiger van het machtige bedrijf en het slachtoffer in de een-op-eendialoog. Anderzijds zou het ook disproportioneel zijn om een dialoog tussen een vertegenwoordiger van het bedrijf en een grote groep slachtoffers te organiseren, gaven de respondenten aan. 
Wie vertegenwoordigt de rechtspersoon aan de bemiddelingstafel?

Het verduidelijken van wie rond de bemiddelingstafel zal zitten, vormt een integraal onderdeel van het bemiddelingsproces. Bij traditionele misdrijven is het meestal duidelijk wie de 'partijen' zijn, voor bedrijfsgeweld moet dat uitgeklaard worden. Het is goed mogelijk dat het bemiddelingsproces zowel een bedrijfsvertegenwoordiger van het middenkader nodig heeft, die de feiten en hun omstandigheden kan toelichten en iemand die het hoogste niveau van het bedrijf vertegenwoordigt, die namens het bedrijf verantwoordelijkheid kan nemen voor wat er gebeurd is. Een genoemd voorbeeld van een zeldzaam geval van bedrijfsgeweld waarin bemiddeld was, betrof een geval van elektrocutie op het werk. Het bedrijf wilde de directeur personeelszaken naar de bemiddelingstafel sturen, maar het slachtoffer weigerde en wilde de CEO zelf confronteren, omdat hij verantwoordelijk was voor het bedrijfsbeleid. Dit is ook wat er uiteindelijk gebeurde.

\section{De specifieke context van bedrijfsgeweld}

De bemiddelaars moeten zich inwerken in thema's zoals bedrijfscriminaliteit, strafrechtelijke aansprakelijkheid van bedrijven en milieucriminaliteit, die geen deel uitmaken van hun huidige professionele bagage, die veel meer gericht is op conventionele misdrijven en hun gevolgen.

\section{Conclusie}

In deze bijdrage verkenden we de in de empirische criminologie wat 'vergeten' groep van slachtoffers van bedrijfsgeweld. Met bedrijfsgeweld bedoelen we situaties waarin bedrijven in de loop van hun legale activiteiten misdrijven plegen die schade teweegbrengen aan de gezondheid, integriteit of het leven van natuurlijke personen. De verkenning werd uitgevoerd aan de hand van de uitkomsten van het Europese project 'Victims and Corporations', waarbinnen casussen werden bestudeerd en interviews en focusgroepen werden georganiseerd met slachtoffers zelf en professionals die met slachtoffers van bedrijfsgeweld in contact kwamen. Zo kregen we niet alleen zicht op de typische kenmerken van dit type slachtofferschap, maar ook op de schadelijke effecten van bedrijfsgeweld en de problematische aspecten van de aanpak van dergelijke situaties via een strafprocedure. Daaruit volgde de logische vraag of een herstelrechtelijke aanpak een aantal van die problemen zou kunnen overstijgen, om zo tot meer bevredigende oplossingen te komen voor de betrokken slachtoffers. Die vraag kon in het bestek van dit artikel niet beantwoord worden. Wel konden we vaststellen dat casussen van bedrijfsgeweld in de huidige Belgische bemiddelingspraktijk uiterst zeldzaam zijn. Uit de bevraging van herstelrechtprofessionals bleek wel dat zij hier een vruchtbaar terrein zien dat verdere verkenning waard is, waarbij wel een aantal aspecten grondig onder de loep dient genomen te worden. Cruciaal wordt bijvoorbeeld de vraag of bedrijven, waarvan het handelen in grote mate gedreven lijkt door het vermijden van juridische aansprakelijkheid en reputatieschade, bereid zullen gevonden worden om vrijwillig de dialoog aan te gaan met hun slachtoffers. 


\section{Literatuur}

Lauwaert, K. (2017a) Individual assessment of corporate violence victims' needs. A practical guide. Milan: Università Cattolica del Sacro Cuore, laatst geconsulteerd op 19 maart 2019, www.victimsandcorporations.eu/wp-content/uploads/2018/04/ Individual-assessm.corp_.violence-victims.Apr_2017.pdf.

Lauwaert, K. (2017b) Strafbaar gedrag van bedrijven en schending van fysieke integriteit: ervaringen en noden van slachtoffers. Een praktijkgids. Leuven: KU Leuven, laatst geconsulteerd op 19 maart 2019, www.victimsandcorporations.eu/wp-content/ uploads/2018/05/VictCorp_Indiv-Assess-_DUTCH-praktijksgids-2017.pdf.

Lauwaert, K. (2017c) Strafbaar gedrag van bedrijven en schending van fysieke integriteit. Richtlijnen voor slachtofferzorg en diensten herstelrecht en bemiddeling. Leuven: Leuvens Instituut voor Criminologie, laatst geconsulteerd op 19 maart 2019, www. victimsandcorporations.eu/wp-content/uploads/2017/12/Richtlijnen-voorslachtofferzorg-en-diensten-herstelrecht-en-bemiddeling.pdf.

Lauwaert, K. (2017d) National report Belgium. In: Needs of victims of corporate violence: empirical findings. Milan: Università Cattolica del Sacro Cuore (p. 97-128), laatst geconsulteerd op 19 maart 2019, www.victimsandcorporations.eu/wp-content/ uploads/2018/05/VictCorp_Empiric.Findings_COMPREHENS.REPORT.pdf.

Tombs, S. (2007) Violence, safety crimes and criminology. British Journal of Criminology, 47, 531-550.

Visconti, A. (2018) Corporate violence: harmful consequences and victims' needs. An overview. In: C. Mazzucato, A. Visconti \& S. Giavazzi (eds.), Victims and Corporations. Legal challenges and empirical findings (p. 149-177), Milaan: Wolters Kluwer.

Walklate, S. (1989) Victimology: the victim and the criminal justice process. New York: Routledge. 